\title{
Front matter: Volume 9441
}

, "Front matter: Volume 9441," Proc. SPIE 9441, 19th Polish-Slovak-Czech Optical Conference on Wave and Quantum Aspects of Contemporary Optics, 944101 (11 December 2014); doi: 10.1117/12.2182693

SDIE Event: XIX Polish-Slovak-Czech Optical Conference on Wave and Quantum SPIE. Aspects of Contemporary Optics, 2014, Jelenia Gora, Poland 


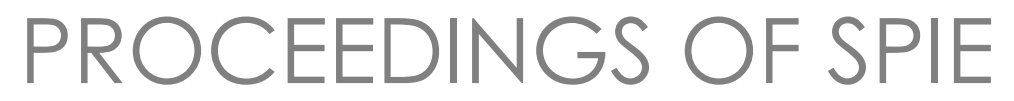

\title{
19th Polish-Slovak-Czech Optical Conference on Wave and Quantum Aspects of Contemporary Optics
}

\author{
Agnieszka Popiołek-Masajada \\ Waclaw Urbańczyk \\ Editors
}

\section{8-12 September 2014 \\ Jelenia Góra, Poland}

Organized by

Institute of Physics, Wrocław University of Technology (Poland)

Published by

SPIE 
The papers included in this volume were part of the technical conference cited on the cover and title page. Papers were selected and subject to review by the editors and conference program committee. Some conference presentations may not be available for publication. The papers published in these proceedings reflect the work and thoughts of the authors and are published herein as submitted. The publisher is not responsible for the validity of the information or for any outcomes resulting from reliance thereon.

Please use the following format to cite material from this book:

Author(s), "Title of Paper," in 19th Polish-Slovak-Czech Optical Conference on Wave and Quantum Aspects of Contemporary Optics, edited by Agnieszka Popiołek-Masajada, Wacław Urbańczyk, Proceedings of SPIE Vol. 9441 (SPIE, Bellingham, WA, 2014) Article CID Number.

ISSN: 0277-786X

ISBN: 9781628415568

Published by

SPIE

P.O. Box 10, Bellingham, Washington 98227-0010 USA

Telephone +1 3606763290 (Pacific Time) · Fax +1 3606471445

SPIE.org

Copyright (@ 2014, Society of Photo-Optical Instrumentation Engineers.

Copying of material in this book for internal or personal use, or for the internal or personal use of specific clients, beyond the fair use provisions granted by the U.S. Copyright Law is authorized by SPIE subject to payment of copying fees. The Transactional Reporting Service base fee for this volume is $\$ 18.00$ per article (or portion thereof), which should be paid directly to the Copyright Clearance Center (CCC), 222 Rosewood Drive, Danvers, MA 01923. Payment may also be made electronically through CCC Online at copyright.com. Other copying for republication, resale, advertising or promotion, or any form of systematic or multiple reproduction of any material in this book is prohibited except with permission in writing from the publisher. The CCC fee code is 0277-786X/14/\$18.00.

Printed in the United States of America.

Publication of record for individual papers is online in the SPIE Digital Library.

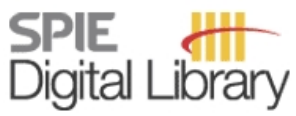

SPIEDigitalLibrary.org

Paper Numbering: Proceedings of SPIE follow an e-First publication model, with papers published first online and then in print. Papers are published as they are submitted and meet publication criteria. A unique citation identifier (CID) number is assigned to each article at the time of the first publication. Utilization of CIDs allows articles to be fully citable as soon as they are published online, and connects the same identifier to all online, print, and electronic versions of the publication. SPIE uses a six-digit CID article numbering system in which:

- The first four digits correspond to the SPIE volume number.

- The last two digits indicate publication order within the volume using a Base 36 numbering

system employing both numerals and letters. These two-number sets start with 00, 01, 02, 03, 04, $05,06,07,08,09,0 A, 0 B \ldots$. OZ, followed by 10-1Z, 20-2Z, etc.

The CID Number appears on each page of the manuscript. The complete citation is used on the first page, and an abbreviated version on subsequent pages. 


\title{
Contents
}

\author{
vii Authors \\ ix Conference Committees \\ xiii Introduction
}

\section{SESSION 1 OPTICAL TRAPPING}

944102 Behaviour of a non-spherical metal nanoparticle in an optical trap [9441-51]

944103 Particles in motion driven by optical binding [9441-64]

$944104 \quad$ Tractor beam in micro-scale [9441-49]

944105 Experimental analysis of multiple-beam interference optical traps [9441-48]

944106 Manipulation of metal-dielectric core-shell particles in optical fields [9441-68]

944107 Raman tweezers in microfluidic systems for analysis and sorting of living cells [9441-65]

944108 Liquid crystal emulsion micro-droplet WGM resonators [9441-54]

944109 Light induced particle organization in paramagnetic fluids [9441-6]

\section{SESSION 2 LASERS AND THEIR APPLICATIONS}

9441 OA Watt-level, fluoride fiber-based supercontinuum light sources with efficient power distribution in the mid-infrared (Invited Paper) [9441-29]

$9441 \mathrm{OB}$ Thulium-doped optical fibers and components for fiber lasers in $\mathbf{2} \boldsymbol{\mu m}$ spectral range (Invited Paper) [9441-30]

9441 OC Design and characterization of beam shapers for end-pumped lasers [9441-8]

9441 OD Iron bulk lasers working under cryogenic and room temperature [9441-52]

$9441 \mathrm{OE} \quad 1.2 \mathrm{~W}$ actively mode-locked Tm:YLF laser [9441-39]

9441 OF Diffraction-limited, grazing-incidence $\mathrm{Nd}: \mathrm{YVO}_{4}$ slab laser side pumped by 2D laser diode stack [9441-56]

9441 OG Tapered fiber bundle couplers for high-power fiber amplifiers [9441-25]

$9441 \mathrm{OH} \quad$ Passively mode-locked quasi-continuously end-pumped Yb:YAG laser at room and cryogenic temperatures [9441-14] 
9441 Ol Diode pumped Yb-lasers Q-switched by V:YAG saturable absorber [9441-33]

9441 OJ Graphene-chitosan self-start ultrafast laser setup [9441-22]

9441 OK Graphene oxide paper as a saturable absorber for Er-doped fiber laser [9441-17]

9441 OL Spectral properties of iodine cells for laser standards [9441-28]

\section{SESSION $3 \quad$ OPTICAL IMAGING}

$94410 M \quad$ Beam shifts to reflected light beams and their axial structure [9441-32]

$9441 \mathrm{ON}$ Optimizing the rotating point spread function by SLM aided spiral phase modulation [9441-35]

944100 Optical sectioning microscopy using two-frame structured illumination and Hilbert-Huang data processing [9441-55]

9441 OP Near-field scanning optical microscopy and lithography for LED characterization and semiconductor patterning [9441-36]

$94410 Q \quad$ Phase retrieval from the optical vortex scanning microscopy [9441-5]

\section{SESSION $4 \quad$ X-RAY OPTICS}

9441 OR Laser-plasma SXR/EUV sources: adjustment of radiation parameters for specific applications (Invited Paper) [9441-15]

9441 OS Diffraction and frequency combs in MeV region [9441-27]

9441 OT Soft x-ray solar polarimeter-spectrometer [9441-63]

\section{SESSION 5 QUANTUM OPTICS}

$9441 \mathrm{OU}$ Three-mode system of nonlinear quantum oscillators and quantum correlations [9441-16]

9441 OV Spontaneous parametric down conversion in nonlinear metallo-dielectric layered media [9441-9]

9441 OW System of nonlinear quantum oscillator and quantum correlations: proposal for quantum chaos indicator [9441-45]

$94410 X \quad$ Entropic measure of disorder in a system of two-level atoms in 2D cavity-cellular automata approach [9441-70]

9441 OY Entanglement and nonclassicality of twin beams containing noise [9441-31] 
$94410 Z$ Wavelet transform in fringe separation [9441-53]

944110 Phase evaluation in FTM interferometry using piecewise quadratic function [9441-10]

944111 Evaluation of optical parameters of quasi-parallel plates with single-frame interferogram analysis methods and eliminating the influence of camera parasitic fringes [9441-13]

944112 Evaluation of the implicit smoothing splines algorithm for the interferometric fringe pattern phase retrieval [9441-59]

944113 Coherent optics in students' laboratories [9441-43]

944114 Application of the fibre optic interferometer as a rotational seismograph type AFORS [9441-7]

944115 White-light interferometry with high measurement speed [9441-21]

944116 Analysis of interferograms of refractive index inhomogeneities produced in optical materials [9441-24]

\section{SESSION 7 OPTICAL FIBERS AND NONLINEAR OPTICS}

944117 Recent advancements towards green optical networks (Invited Paper) [9441-19]

944118 Fabrication of optical waveguide structures based on PDMS using photoresist fibers [9441-47]

944119 Capabilities of DLW for fabrication of planar waveguides in PDMS [9441-46]

9441 1 A Wavelength demodulation system for embedded FBG sensors using a highly birefringent fiber [9441-66]

9441 1B Air core Bragg fibers for delivery of near-infrared laser radiation [9441-44]

9441 1C Refractive index fiber sensor based on cladding modes interference [9441-37]

9441 1D Dual-core microstructure optical fiber as a potential polarization splitter [9441-38]

9441 1E Magneto-optics: from bulk materials to nanostructures [9441-71]

9441 IF Crystalline composition of silicon deposited on a low-cost substrate for photovoltaic applications studied by in-situ spectroscopic ellipsometry [9441-69]

$94411 G$ On the optical properties of plasmonic glasses [9441-67] 
$9441 \mathrm{1H} \quad$ Surface plasmon resonance based fiber optic refractive index sensors [9441-23]

$944111 \quad$ Model of a double-sided surface plasmon resonance fiber optic sensor [9441-61]

\section{SESSION 9 OPTICAL MEASUREMENTS}

$94411 \mathrm{~J}$ Dispersive and BEMA investigation on optical properties of photovoltaic thin films (Invited Paper) [9441-34]

$94411 \mathrm{~K}$ Optical methods for the measurement of the shape of objects and their measurement uncertainty (Invited Paper) [9441-20]

$9441 \mathrm{lL}$ Time-resolved fluorescence monitoring of cholesterol in peripheral blood mononuclear cells [9441-4]

9441 1M Reproducible and time-course study of yeast biofilm by Raman spectroscopy [9441-58]

$94411 \mathrm{~N}$ Recent developments in remote gas detection using molecular dispersion sensing [9441-26]

$944110 \quad$ Far-field pattern modification of LEDs with 2D PhC PDMS membrane [9441-50]

9441 1P Analysis of imaging properties of active lenses with spherical surfaces of independently variable curvature [9441-11]

9441 1Q Elliptical analyzer and plurality of light polarization state singularities [9441-72]

9441 IR Performance of a new high sensitivity polarimeter [9441-62]

9441 is Optical system of borescope for flame observation in visible (VIS) and infrared (NIR) part of light [9441-18]

$94411 \mathrm{~T}$ Optical investigation of the AIGaAs/GaAs LED with photonic structures patterned by the EBDW lithography [9441-40] 


\section{Authors}

Numbers in the index correspond to the last two digits of the six-digit citation identifier (CID) article numbering system used in Proceedings of SPIE. The first four digits reflect the volume number. Base 36 numbering is employed for the last two digits and indicates the order of articles within the volume. Numbers start with 00, 01, 02, 03, 04, 05, 06, 07, 08, 09, OA, OB...0Z, followed by 10-1Z, 20-2Z, etc.

Aas, Mehdi, 08

Abramski, Krzysztof M., OG, OJ, OK

Acef, Ouali, OL

Andok, R., $1 \mathrm{~T}$

Antosiewicz, Tomasz J., $1 G$

Apell, S. Peter, $1 G$

Arkhipov, I., OY

Bacia, Marcin, 09

Bakała, Jarosław, OT

Baránek, M., ON

Bartnik, A., OR

Bartonek, Ludek, is

Bencurova, A., OP

Bernatová, Silvie, 1M

Bieda, Marcin, 1A

Bogusławski, Jakub, OJ, OK

Borwińska, Monika, IR

Bouchal, Z., ON

Brzobohatý, Oto, 02, 04, 08

Buczynski, Ryszard, 1D

Bugar, Ignac, 1D

Buis, Adrianus, 17

Cajzl, Jakub, OB

Chea, Erick, OL

Chen, Lawrence, 17

Chiodo, Nicola, OL

Chvátal, Lukáš, 02, 04, 06

Číp, Ondřej, OL

Ciprian, Dalibor, $1 \mathrm{H}, 1 \mathrm{I}$

Čižmár, T., 04

Cupal, Josef, $\mathrm{OH}$

Curilla, Lubomir, 1D

Davidson, Alan, 17

Dennis, Mark R., OM

Domański, Andrzej W., IA

Doroshenko, M. E., OD

Drobczyński, Sławomir, 09

Drzik, Milan, 13

Du Burck, Frédéric, OL

Fiedorowicz, Henryk, OR

Fok, T., OR

Foldyna, M., 1F

Frank, Milan, 1B

Gaso, Peter, 18, 19, 10

Gerasimenko, A. S., OD

Glesk, Ivan, 17

Gogler, Sławomir, OC

Gorajek, Łukasz, OC, OF

Götte, Jörg B., OM
Halagačka, L., 1E

Hlubina, Petr, 1H, 11

Holá, Miroslava, OL

Holešinský, J., IF

Honzátko, Pavel, OB

Horilova, J., $1 \mathrm{~L}$

Hrabina, Jan, OL

Hrabovský, Miroslav, is

Hronec, Pavol, 10, $1 \mathrm{~T}$

Indykiewicz, Kornelia, OQ

Jabczyński, Jan K., OC, OF, OI

Jagiełło, Joanna, OJ

Jákl, Petr, 05

Jandura, Daniel, 18, 19

Jarocki, R., OR

Jaroszewicz, Leszek R., 14

Javưrek, D., OV

Jelínek, Michal, OD, OE, OH, 1B

Jelínková, Helena, OD, OI

Ježek, Jan, 07, 08, 1M

Jonáš, Alexandr, 08

Kacik, Daniel, $1 \mathrm{C}$

Kaczmarek, Pawel, OG

Kadulova, Miroslava, $1 \mathrm{H}$

Kalaga, J. K., OU, OW

Kamiński, Jerzy Z., OS

Kaňka, Jan, 07

Karásek, Vítězslav, 02, 03, 04

Kašík, Ivan, OB, 1B

Kaśków, Mateusz, OC, OF, OI

Keprt, Jirí, is

Kiraz, Alper, 08

Komar, V. K., OD

Kostecki, J., OR

Kováč, Jaroslav, OP, 10, $1 \mathrm{~T}$

Kovalenko, N. O., OD

Kowalewska-Kudłaszyk, A., OU, OW

Kowaliński, Mirosław, OT

Kowalski, Jerzy K., 14

Kozinski, Rafal, OK

Krajewska, Katarzyna, OS

Krajewski, Zbigniew, 14

Kryžánek, Vladislav, 1M

Kubeček, Václav, OE, OH, 1B

Kuczkowski, Michał, 1A

Kurzych, Anna, 14

Kurzynowski, Piotr, 1Q, 1R

Kutrowska, Joanna, 09

Kuzin, Sergey, OT 
Kwiatkowski, Jacek, OC

Lajdova, I., $1 \mathrm{~L}$

Lamperska, Weronika, 09

Langhammer, Christoph, $1 \mathrm{G}$

Laurencikova, A., OP

Lazar, Josef, OL

Leoński, Wiesław, OU, OW, OX

Lesiak, Piotr, $1 \mathrm{~A}$

Lettrichova, Ivana, OP, 10

Librant, Krzysztof, OK

Lipinska, Ludwika, OJ, OK

Long, Van Cao, OX

Marcek Chorvatova, A., $1 \mathrm{~L}$

Martinakova, Z., $1 \mathrm{~L}$

Martincek, Ivan, 18

Masajada, Jan, 09, 0Q

Matějec, Vlastimil, 1B

Mesaros, Vladimir, 13

Mikš, Antonín, IP

Miranowicz, Adam, OY

Mlynariková, Katarina, 1M

Mrázková, Z., 1 F

Müllerová, Jarmila, $1 \mathrm{~J}$

Mužík, Jiří, OE

Němec, M., OD

Netrvalová, Marie, $1 \mathrm{~J}$

Nguyen, Thanh Vinh, OX

Nikodem, Michal, $1 \mathrm{~N}$

Nolte, Rainer, 10

Novak, J., OP

Novák, Jiří, IP

Novák, Pavel, IP

Paszkiewicz, Regina, $0 Q$

Patorski, Krzysztof, 00, 0Z, 11, 12

Pavliček, Pavel, 15, 1K

Peřina, J., OY

Peřina, Jan, Jr., OV, OY

Peterka, Pavel, OB

Piasecki, Michał, OC, OF

Pilát, Zdeněk, 07, 08

Pištora, J., 1E, $1 \mathrm{~F}$

Płocieniak, Stefan, OT

Podrazký, Ondřej, OB, 1B

Pokorný, Petr, 10, 1P

Pokorski, Krzysztof, 0Z, 11

Popiołek-Masajada, Agnieszka, $0 Q$

Pospišil, Ladislav, is

Postava, K., 1E, 1F

Prušáková, Lucie, $1 \mathrm{~J}$

Pudiš, Dusan, OP, 18, 19, 10, $1 \mathrm{~T}$

Puzikov, V. M., OD

Roca i Cabarrocas, P., IF

Růžička, Filip, 1M

Samek, Ota, IM

Šarbort, Martin, OL

Schaaf, Peter, 10

Schuster, Kay, 1C

Senderakova, Dagmar, 13

Siarkowski, Marek, OT

Šiler, Martin, 02, 04, 05, 06, 1M
Škriniarová, J., OP, IT

Sliwinska, Dorota, OG

Sobon, Grzegorz, OJ, OK

Sotor, Jaroslaw, OJ, OK

Stajanca, Pavol, 1D

Stęślicki, Marek, OT

Šulc, Jan, OD, Ol

Sunderland, Zofia, 11

Suslik, Lubos, 10

Šutta, Pavol, $1 \mathrm{~J}$

Svak, Vojtěch, 15

Svozilík, J., OV

Swiderski, J., OA

Sylwester, Janusz, OT

Szaforz, Żaneta, OT

Szatkowski, Mateusz, OQ

Szczurek, A., OR

Szczurek, M., OR

Szelag, Mateusz, 1 A

Tarjányi, N., 16

Tarka, Jan, OJ, OK

Tatar, Peter, 1C

Teisseyre, Krzysztof P., 14

Tkaczyk, T., 00

Torres-Rios, A., IF

Trusiak, M., 00

Uherek, František, 1D, IT

Vanwolleghem, M., IE

Vávra, I., IF

Vodárek, V., $1 \mathrm{~F}$

Vyhlídal, David, $\mathrm{OE}, \mathrm{OH}$

Wachulak, P., OR

Walczak, Katarzyna, 09

Wang, Junjia, 17

Węgrzyński, Ł., OR

Wielgus, Maciek, 11, 12

Woliński, Tomasz R., 1 A

Woźniak, Władysław A., IR

Zagorviko, Y. A., OD

Zawadzki, Zbigniew, OC

Zdunek, Marzena, IR

Zemánek, Pavel, 02, 03, 04, 05, 06, 07, 08, 1M

Zendzian, Waldemar, OF 


\title{
Conference Committees
}

\author{
Conference Chair
}

Wacław Urbańczyk, Wrocław University of Technology (Poland)

\section{Conference Program Committee}

Krzysztof Abramski, Wrocław University of Technology (Poland) Henryk Fiedorowicz, Military University of Technology (Poland)

Wojciech Gawlik, Jagiellonian University, Kraków (Poland) Ivan Glesk, University of Strathclyde (United Kingdom)

Ondřej Haderka, Palacky University in Olomouc, Joint Laboratory of Optics (Czech Republic)

Petr Hlubina, Technical University, Ostrava (Czech Republic)

Zdeněk Hradil, Palacký University, Olomouc (Czech Republic)

Jan Jabczyński, Military University of Technology (Poland)

Leszek R. Jaroszewicz, Military University of Technology, Warsaw (Poland)

Helena Jelínková, Czech Technical University in Prague

(Czech Republic)

Mirosław Karpierz, Warsaw University of Technology (Poland)

Henryk Kasprzak, Wrocław University of Technology (Poland)

Andrzej Kolodziejczyk, Warsaw University of Technology (Poland)

Andrzej Kowalczyk, Nicolaus Copernicus University, Toruń (Poland)

Wieslaw Leoński, University of Zielona Góra (Poland)

Jan Masajada, Wrocław University of Technology (Poland)

Adam Miranowicz, Adam Mickiewicz University, Poznań (Poland)

Jarmila Müllerová, University of Žilina (Slovakia)

Krzysztof Patorski, Warsaw University of Technology (Poland)

Jan Peřina, Jr., Institute of Physics of Academy of Sciences of the

Czech Republic, Olomouc (Czech Republic)

Ladislav Pina, Czech Technical University in Prague (Czech Republic)

Dusan Pudiš, University of Žilina (Slovakia)

Tadeusz Pustelny, Silesian University of Technology, Gliwice (Poland)

Ivan Richter, Czech Technical University in Prague (Czech Republic)

Dagmar Senderáková, Comenius University, Bratislava (Slovakia)

Tomasz Szoplik, University of Warsaw (Poland)

František Uherek, Slovak University of Technology and International Laser Center, Bratislava (Slovakia)

Pavel Veis, Comenius University, Bratislava (Slovakia)

Ewa Weinert-Raczka, West Pomeranian University of Technology, Szczecin (Poland)

Tomasz R. Woliński, Warsaw University of Technology (Poland)

Pavel Zemánek, Institute of Scientific Instruments of the ASCR, v.v.i., Brno (Czech Republic) 


\section{Organizing Committee}

Agnieszka Popiołek-Masajada, Wrocław University of Technology

(Poland)

Alicja Anuszkiewicz, Wrocław University of Technology (Poland)

Marcin Bacia, Wrocław University of Technology (Poland)

Sławomir Drobczyński, Wrocław University of Technology (Poland)

Katarzyna Gasior, Wrocław University of Technology (Poland)

Agnieszka Jóźwik, Wrocław University of Technology (Poland)

Dominik Kowal, Wrocław University of Technology (Poland)

Maciej Napiórkowski, Wrocław University of Technology (Poland)

Tadeusz Przerwa-Tetmajer, Wrocław University of Technology (Poland)

Gabriela Statkiewicz-Barabach, Wrocław University of Technology

(Poland)

Karol Tarnowski, Wrocław University of Technology (Poland)

Marzena Zdunek, Wrocław University of Technology (Poland)

\section{Session Chairs}

Hot Topics

Wacław Urbańczyk, Wrocław University of Technology (Poland)

Jirí Homola, Institute of Photonics and Electronics of the ASCR, v.v.i.

(Czech Republic)

Lasers and Their Applications

Helena Jelínková, Czech Technical University in Prague

(Czech Republic)

Jarmila Müllerová, University of Žilina (Slovakia)

Quantum Optics

Jan Peřina, Jr., Institute of Physics, Olomouc (Czech Republic)

Konrad Banaszek, University of Warsaw (Poland)

X-ray Optics

Henryk Fiedorowicz, Military University of Technology, Warsaw

(Poland)

Ladislav Pina, Czech Technical University in Prague (Czech Republic)

Magneto-optics/Optical Imaging

Tomasz Szoplik, University of Warsaw (Poland)

Oto Brzobohatý, Institute of Scientific Instruments of the ASCR, v.v.i.

(Czech Republic)

Interferometry and Diffractive Optics

Pavel Pavlicek, Palacký University, Olomouc (Czech Republic) 
Optical Fibers and Nonlinear Optics

Tomasz R. Woliński, Warsaw University of Technology (Poland)

Plasmonics

František Uherek, Slovak University of Technology and International Laser Center, Bratislava (Slovakia)

Optical Measurements/Optical Trapping

Dusan Pudišs, University of Žilina (Slovakia)

Petr Hlubina, Technical University, Ostrava (Czech Republic)

Jan Masajada, Wrocław University of Technology (Poland) 
Proc. of SPIE Vol. $9441944101-12$

Downloaded From: https://www.spiedigitallibrary.org/conference-proceedings-of-spie on 25 Apr 2023 Terms of Use: https://www.spiedigitallibrary.org/terms-of-use 


\section{Introduction}

The 19th Polish-Slovak-Czech Optical Conference on Wave and Quantum Aspects of Contemporary Optics was held 8-12 September 2014 in Wojanów Palace near Jelenia Góra, a modern SPA and conference center situated in newly renovated buildings of a historical romantic manorial residency. This magnificent place with its relaxed atmosphere provided an ideal setting for an enjoyable meeting. For over 40 years, the Polish-Slovak-Czech Optical Conference stimulates an exchange of ideas among academic and industrial communities of the three organizing countries. This conference series was originated in the early 1970 s and now takes place every two years alternating in turn from Poland, Slovakia, and the Czech Republic.

The 19th conference was organized by the Institute of Physics, Wrocław University of Technology, Poland and covered several aspects of modern optics, including quantum and nonlinear optics, x-ray and UV optics, lasers and laser-assisted manufacturing, wave and geometrical optics, waveguide optics, optical trapping, plasmonics, magnetooptics, optical communication, optical metrology, design and manufacture of optical components, education for research, and training in optics. The conference attracted 151 participants, among them 85 from Poland, 38 from the Czech Republic, 20 from Slovakia, and 8 from other countries (Germany-3, United Kingdom-2, Italy-1, Australia-1, Russia-1). The participants had an opportunity to listen to 26 invited and 56 regular lectures. Moreover, there were 59 posters presentations covering a broad range of topics. These proceedings contain 6 invited papers and 58 regular papers reviewed by the members of the Technical Program Committee.

The 19th Polish-Slovak-Czech Optical Conference could not be so successful without involvement of many people, including members of the Organizing Committee and the Technical Program Committee, invited lecturers, and session chairs. We would like to express our gratitude and appreciation for their contribution. Finally, we wish our colleagues from Slovakia, who are now responsible for organizing the twentieth Slovak-Czech-Polish Optical Conference in 2016, a successful meeting and satisfaction in their work related to the conference preparation.

\section{Agnieszka Popiołek-Masajada Wacław Urbańczyk}


Proc. of SPIE Vol. $9441944101-14$

Downloaded From: https://www.spiedigitallibrary.org/conference-proceedings-of-spie on 25 Apr 2023 Terms of Use: https://www.spiedigitallibrary.org/terms-of-use 